\title{
Electrodiagnostics or Ultrasound for Diagnosing Diabetic Peripheral Neuropathy [Letter]
}

This article was published in the following Dove Press journal:

Diabetes, Metabolic Syndrome and Obesity: Targets and Therapy

\author{
Otto Jesus Hernandez Fustes ${ }^{\prime}$ \\ Olga Judith Hernandez Fustes ${ }^{2}$ \\ 'Neurology Service, Complexo Hospital \\ de Clinicas-Universidade Federal do \\ Paraná, Curitiba, Brazil; \\ ${ }^{2}$ Neurophysiology Service, Clínica \\ Neurológica das Américas, Curitiba, \\ Brazil
}

\section{Dear editor}

We read with great interest the manuscript by Huang and Wu about "Application of High-Resolution Ultrasound on Diagnosing Diabetic Peripheral Neuropathy". ${ }^{1}$

This review is an opportunity to discuss diagnostic aspects of a very important disease.

We think the article offers a good opportunity for resident physicians and specialists to review and discuss diagnostic aspects of diabetic peripheral neuropathy (DPN).

The management of people with small fiber neuropathy (SFN) is a challenge not only for the neurologist or pain specialist but also for the neurophysiologist. The fact of having to find evidence to support clinical complaints when routine studies of nerve conduction are normal, has led to the development in recent years of several procedures, neurophysiological, histological and imaging, allowing the advancement in diagnosis without considering specific markers.

Neurophysiological methods available to assess possible SFN consist of quantitative sensory test, reflex of the sudomotor axon, sympathetic skin response, autonomic tests, and potentials evoked by laser. These techniques are partially invasive, time consuming, expensive, and therefore just partially useful in the clinical routine.

Pain-related evoked potentials (PREP) might be an alternative because it is a noninvasive, reliable electrophysiological procedure which can assess the signal transmission of A-delta fibers without large expenditure. PREP detect small fiber dysfunctions in systemic disorders which are associated with generalized polyneuropathies. ${ }^{2}$

The development and use of new imaging techniques (such as high-resolution ultrasound) and electrophysiological techniques like PREP, without a doubt adds a new option to the diagnosis and management of neuropathies and in particular small fiber neuropathy, in addition to facilitating more comprehensive studies that allow us to achieve more reliable conclusions. ${ }^{3}$

We agree with the authors when they conclude that combining ultrasound and nerve conduction examination can improve the diagnostic value of this method for DPN and avoid missed diagnoses and misdiagnosis. ${ }^{1}$

In our opinion, imaging and neurophysiological methods are not mutually exclusive, in DPN, they can add evidence for a faster and more specific diagnosis, enabling adequate management of such an important medical condition.

Huang and $\mathrm{Wu}$ performed an important and extensive review of the role of HRU in the diagnosis of DPN. We congratulate the authors for doing this, and for providing the opportunity to delve into a topic so interesting.
Correspondence: Otto Jesus Hernandez Fustes

Neurology Service, Complexo Hospital de Clinicas-Universidade Federal do Paraná, Av. Marechal Floriano 170, Sala 1509, Curitiba, 80090-020, Brasil Email otto.fustes@hc.ufpr.br 


\section{Disclosure}

The authors report no conflicts of interest in this communication.

\section{References}

1. Huang H, Wu S. Application of high-resolution ultrasound on diagnosing diabetic peripheral neuropathy. Diabetes Metab Syndr Obes. 2021;14:139-152. doi:10.2147/DMSO.S292991.
2. Fischer M, Höffkenb O, Özgülb OS, Maier C. Bilaterally prolonged latencies of pain-related evoked potentials in peripheral nerve injuries. Neurosci Lett. 2018;684:78-85. doi:10.1016/j.neulet.2018.07.002

3. Hernandez Fustes OJ. Focus on nerve fiber type: a diagnostic strategy for diabetic polyneuropathy. J Diabetes Investig. 2020. doi:10.1111/ jdi.13434.

Dove Medical Press encourages responsible, free and frank academic debate. The content of the Diabetes, Metabolic Syndrome and Obesity: Targets and Therapy 'letters to the editor' section does not necessarily represent the views of Dove Medical Press, its officers, agents, employees, related entities or the Diabetes, Metabolic Syndrome and Obesity: Targets and Therapy editors. While all reasonable steps have been taken to confirm the content of each letter, Dove Medical Press accepts no liability in respect of the content of any letter, nor is it responsible for the content and accuracy of any letter to the editor.

Diabetes, Metabolic Syndrome and Obesity: Targets and Therapy

\section{Publish your work in this journal}

Diabetes, Metabolic Syndrome and Obesity: Targets and Therapy is an international, peer-reviewed open-access journal committed to the rapid publication of the latest laboratory and clinical findings in the fields of diabetes, metabolic syndrome and obesity research. Original research, review, case reports, hypothesis formation, expert opinion and commentaries are all considered for publication. The manuscript management system is completely online and includes a very quick and fair peer-review system, which is all easy to use. Visit http://www.dovepress.com/testimonials.php to read real quotes from published authors. 